\title{
STATE TRADING IN WESTERN EUROPE
}

\section{Marc Ouis*}

\section{INTRODUCTION}

This study attempts an analysis of state trading in members countries of the Organization for European Economic Cooperation, its scale and character, and the administrative methods followed. The term "state trading" is taken to mean import trade under a government-controlled monopoly, whether the control is directly exercised by government services or is delegated to specialized agencies or groups. The case of exports administered under a government monopoly is not considered here. Moreover, it seems to be of only limited importance in West European countries.

The geographical area covered by this survey of state trading includes the following countries: Austria, B.L.E.U., Netherlands, Denmark, France, West Germany, Greece, Ireland, Norway, Portugal, Sweden, Switzerland, Turkey, and the United Kingdom.

To begin with, the trend of state trading in these countries since the end of the war will be considered. Its present scale, by country and by products, will then be determined in relation to the countries' total import trade. In each particular case, the procedure for applying state trading will be described. After this, it will be possible to analyze the reasons for still having recourse to such an import system. It will be seen that state trading, having regard to the administrative methods used, may have repercussions on international competition and other countries' export trade. In recent years, it has been deemed desirable, within European international organizations, to set certain limits to each government's freedom to decide its own import policy when it practices state trading. Some rules on the subject have been gradually worked out, first in the OEEC, and more recently within the European Economic Community formed since January I, 1958, by Benelux, West Germany, France, and Italy.

\section{I}

\section{Postwar Trends in State Trading}

The statistical data used for this study are based on intra-European trade-i.e., each country's imports from its OEEC partners and their overseas territories. Table one shows, on the basis of the reference year 1948, the trend in countries' imports under the state-trading system between 1949 and 1958 . The choice of 1948 as a reference year means that the scale of state trading for each of the years 1949 to $195^{8}$ has been assessed by applying 1948 values to the list of goods imported under that system (the list varied from year to year). Table two shows the percentage of total

- Licencié en droit 1942, University of Paris. Deputy Director of Trade and Finance, Organization for European Economic Cooperation. Author, L'O.E.C.E. ET le Marché commun. Les raisons d'etre d'une UNION ÉCONOMIQUE DES DIX-SEPT. (1948). 
TABLE I

Evolution of State-Trading Imports (Intra-European Trade) Between I949 and I958

EXPRESSSED IN VAIUE OF I948 IMPORTs ${ }^{\mathrm{a}}$

\begin{tabular}{|c|c|c|c|c|c|c|c|c|c|c|c|}
\hline & 1949 & 1950 & 1951 & 1952 & 1953 & 1954 & 1955 & 1956 & 1957 & 1958 & $\begin{array}{c}\text { Compari- } \\
\text { son } \\
1949 / 1958\end{array}$ \\
\hline 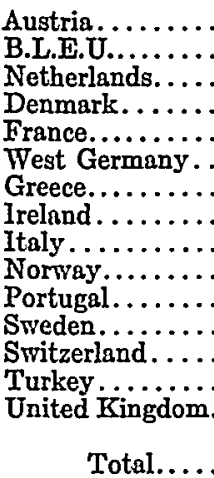 & \begin{tabular}{|}
1.5 \\
52.3 \\
30 \\
16.5 \\
186.6 \\
0 \\
0.2 \\
1.2 \\
15.2 \\
15.8 \\
0 \\
54.3 \\
27.4 \\
6.7 \\
509
\end{tabular} & 25.7 & $\begin{array}{l}49.7 \\
15.9 \\
14.6 \\
54.9\end{array}$ & |818.3 & $\begin{array}{r}11.4 \\
1.9 \\
198.5\end{array}$ & $\begin{array}{l}34.1 \\
32.2 \\
36\end{array}$ & 5.5 & 33.7 & 35.1 & $\begin{array}{c}1.5 \\
0 \\
0 \\
1.9 \\
187.7 \\
54.9 \\
0.2 \\
5.5 \\
15.2 \\
35.1 \\
0 \\
32.2 \\
31.2 \\
6.7 \\
0.6\end{array}$ & $\begin{aligned} & \overline{\overline{5}} \\
&- 52.3 \\
&- 30 \\
& \overline{1} 14.6 \\
&+ 1 \\
&+ 54.9 \\
&+ 4.3 \\
&= \\
&+ 19.3 \\
&==3.1 \\
&+ 3.8 \\
&==808.4 \\
&-544.2\end{aligned}$ \\
\hline
\end{tabular}

- For West Germany, 1949 instead of 1948.

Note: No information being arailable for Iceland, this country was left out of the above table.

imports represented by state trading during the years 1949 to 1958 , using the same reference year 1948 .

TABLE II

Evolution of State-Trading Imports (Intra-European Trade) Between I949 and $195^{8}$ EXPressed In Percentage of I948 Imports ${ }^{\mathrm{a}}$

\begin{tabular}{|c|c|c|c|c|c|c|c|c|c|c|c|}
\hline & 1949 & 1950 & 1951 & 1952 & 1953 & 1954 & 1955 & 1956 & 1957 & 1958 & $\begin{array}{l}\text { Compari- } \\
\text { son } \\
1949 / 1958\end{array}$ \\
\hline 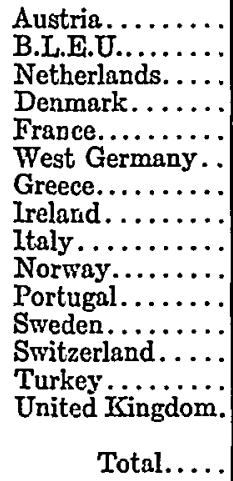 & $\begin{array}{c}1 \\
5.3 \\
3.3 \\
3.7 \\
21.9 \\
0 \\
0.2 \\
0.3 \\
4.6 \\
3.4 \\
0 \\
7.1 \\
4.7 \\
4.7 \\
27.5\end{array}$ & 10.5 & $\begin{array}{l}5.1 \\
1.8 \\
3.3 \\
6.9\end{array}$ & 2.2 & $\begin{array}{r}1.3 \\
0.4 \\
23.3\end{array}$ & $\begin{array}{l}7.4 \\
4.2 \\
1.9 \\
4.5\end{array}$ & 1.6 & 0.5 & 7.7 & $\begin{array}{c}1 \\
0 \\
0 \\
.04 \\
22 \\
6.9 \\
0.2 \\
1.6 \\
4.6 \\
7.7 \\
0 \\
4.2 \\
5.3 \\
4.7 \\
0 \\
4.2\end{array}$ & $\begin{array}{c}= \\
-5.3 \\
-3.3 \\
-3.3 \\
+0.1 \\
+6.9 \\
=1.3 \\
+=4.3 \\
+4 \\
=2.9 \\
+0.6 \\
= \\
-27.5 \\
-5\end{array}$ \\
\hline
\end{tabular}

a For West Germany, 1949 instead of 1948.

Nole: No information being available for Iceland, this country was left out of the above table.

It will be seen from these tables that intra-European imports on government account in OEEC countries as a whole amounted at the end of 1949 , on the basis of the reference year 1948 , to $\$ 917,000,000$ out of a total of $\$ 8,940,000,000$, or 9.2 per 
cent. Of the countries studied, only two did not practice state trading in 1949, West Germany and Portugal. This is still true of the latter. By the end of $195^{8}$, still taking 1948 as a reference year, the value of products imported on government account was no more than $\$ 373,000,000$ out of a total of $\$ 8,940,000,000$, or 4.2 per cent. The fall.in this percentage is due mainly to the return to the private sector of nearly all the products imported on government account by the United Kingdom in 1949, and alone representing 5.7 per cent of that country's total intra-European imports in 1948. Over the last eight years, only five countries have transferred to state trading products previously imported by private importers. The increase in state trading is hardly perceptible for three of these countries-France ( +0.1 per cent), Ireland ( + r.3 per cent), and Switzerland ( +0.3 per cent)-although it is somewhat larger in the case of two of them-Norway $(+4.3$ per cent) and West Germany $(+6.9$ per cent). The increase in state trading for all five countries, however, barely represents I per cent of total intra-European trade, on the basis of 1948 .

The trend of state trading between 1949 and $195^{8}$ in the various countries will now be studied.

\section{Austria, Greece, Italy, Portugal, and Turkey}

Here, there has been no change in the composition of state trading between 1949 and 1958 .

2. B.L.E.U.

$\therefore \quad$ B.L.E.U. imports on government account in 1949 consisted solely of coal products; on the basis of 1948 , they totaled $\$ 52,300,000$ and represented 5.3 per cent of the -B.L.E.U.'s total intra-European imports. The return of lignite to private trading in r95I reduced the percentage to 5.I. The total abolition of the system of government imports was announced by the Belgian and Luxembourg Governments in I954.

\section{Netherlands}

In I949, imports by the Netherlands Government were confined to the agricultural sector, and totaled $\$ 30,000,000$, or 3.3 per cent of the Netherlands' total intra-European imports.: In I95I, the return to private trading of live cattle, beef and veal, horsemeat, and pigmeat reduced government imports to $\$ 15,900,000$, or 1.8 per cent of total intra-European imports. In I953, the further transfer to the private sector of cattle used for preparing serums, animal feedingstuffs, and coffee reduced government imports to $\$ \mathrm{II}, 400,000$, or I.3 per cent of total intra-European imports. Finally, in i954, the system of state trading was completely abolished, with the return to the private sector of cereals, oilseeds, bacon, vegetable oils, fish oils, and hydrogenated oils and fats.

\section{Denmark}

$\therefore$ Danisti imports on government account in 1949 totaled $\$ 16,500,000$, or 3.7 per cent of Denmark's total intra-European imports. When rye was returned to private 
trading in I95I, government imports fell by $\$ 1,900,000$; and in 1952 , they stood at $\$ 8,100,000$, or 1.8 per cent of total intra-European imports, when the following were transferred to the private sector: oats, maize, straw, hay, fodder crops, and byproducts of the food industry. In that same year, however, the Danish Government decided that certain products for the armed forces, arms, ammunition, aircraft, warships, should be transferred to state trading. This meant an increase of $\$ I, 900,000$ in government imports, which then totaled $\$ 10,000,000$, or 2.2 per cent of total intra-European imports. Finally, in 1953 , feedingstuffs to a value of $\$ 8,100,000$ were transferred to the private sector, which left only arms and military equipment, or 0.4 per cent of Denmark's total intra-European imports, subject to state trading.

\section{France}

The total value of French imports on government account has varied only very slightly over the last eight years. It rose from $\$ 186,600,000$, or 21.9 per cent, to $\$ 187,700,000$, or 22 per cent of France's total intra-European imports. The only changes in the composition of state trading during the period were the transfer of imported sugar to government account in $1953(\$ 11,800,000)$, and the return to the private sector in 1954 of imported railway equipment (\$10,800,000).

\section{West Germany}

In 1949, there was no state trading in West Germany. It was introduced only in 1950 , when it accounted for $\$ 14,400,000$ at 1949 values, or I.8 per cent of West Germany's total intra-European imports. In I95I, other products were transferred to state trading (rye, oats, rice, feedingstuffs, meat, and fatstock). This raised imports on government account to $\$ 54,900,000$, or 6.9 per cent of total intra-European imports. West Germany's state trading has remained unaltered in composition since r951.

\section{Ireland}

In 1949, Ireland's total imports on government account amounted to $\$ 1,200,000$, or 0.3 per cent of its total intra-European imports. In 1955, the transfer to state trading of imported barley $(\$ 4,300,000)$ increased government imports from $\$ I, 200,000$ to $\$ 5,500,000$, or r. 6 per cent of Ireland's total intra-European imports-i.e., an increase of 1.3 per cent.

\section{Norway}

In I949, Norway's imports on government account totaled $\$ 15,800,000$, or 3.4 per cent of its total intra-European imports. In I950, certain agricultural imports (dried fruit, sugar, coffee, and oilcake) were transferred to state trading, which meant a consequent increase of $\$ 9,900,000$, bringing imports on government account from 3.4 to 5.6 per cent of Norway's total intra-European imports. In 1954 and r957, respectively, fishing equipment and pharmaceutical products were transferred to state trading, and Norway's total imports on government account thereby rose from 
$\$ 25,700,000$ to $\$ 34,100,000$ and subsequently $\$ 35,100,000-i . e$, from 5.6 per cent to 7.4 and 7.7 per cent of its total intra-European imports, dried fruit having been returned to the private sector in September $195^{6}(\$ 500,000)$. Hence, over the last eight years, Norway's state trading has, in contrast to the trend in most other countries, expanded from 34 to 7.7 per cent of its total intra-European imports.

\section{Sweden}

Sweden's imports on government account in 1949 totaled $\$ 54,300,000$, or 7.I per cent of its total intra-European imports. In 1954, a group of agricultural products (oats, maize, barley, oilseeds, tallow, vegetable and animal oils, and oilcake) were transferred to the private sector. This brought imports on government account down to $\$ 32,200,000$, or 4.2 per cent of Sweden's total intra-European imports. There has been no change since 1954 in the list of Swedish imports on government account; since 1956, however, practically all agricultural and food products, except alcoholic beverages and tobacco, are imported under an extremely liberal system.

\section{xo. Switzerland}

Government imports in 1949 totaled $\$ 27,400,000$, or 4.7 per cent of Switzerland's total intra-European imports. They covered a list of products lengthened in 1954 by the transfer to state trading of certain agricultural products (oats, barley, maize, rice, bread grains, and seed potatoes). Imports on government account thus rose to $\$ 3 \mathrm{I}, 200,000$, or 5.3 per cent of Switzerland's total intra-European imports.

\section{Ir. United Kingdom}

In $1949,27.5$ per cent of the United Kingdom's total intra-European imports were on government account, amounting to $\$ 509,000,000$ out of $\$ 1,851,000,000$. A first cut in state trading was made in 1951, when the percentage fell to 19.7. The biggest reduction, however, was made in 1952 to 1954 ; following the transfer to the private sector of a number of agricultural products (butter, oilseeds, vegetable, animal and fish oils, fats, meats, coffee, eggs, cheese, and canned milk), raw materials (phosphate of lime, superphosphates, tungsten ores and concentrates, unwrought steel, aluminum, copper, lead, zinc, jute, hemp, sulphur, and iron pyrites), and manufactured steel products, imports on government account were no more than $\$ 36,000,000$, or $x .9$ per cent of the United Kingdom's total intra-European imports. In 1956, the transfer of bacon to the private sector further reduced these figures to $\$ 9,600,000$ and 0.5 per cent, respectively. Finally, in 1958 , government imports of potatoes were discontinued, so that the list of products imported under this system was reduced to the single item of jute fabrics, which in the reference year were valued at less than $\$ 1,000,000$.

\section{II}

Present Situation of State Trading by Countries and by Products

Table three shows the breakdown, by countries, of the principal products now imported on government account. Part one of the table represents the situation in 
TABLE III

State-Traded Imports by Countries and by Products (November i, i958)

\begin{tabular}{|c|c|c|c|c|c|c|c|c|c|c|c|c|}
\hline & 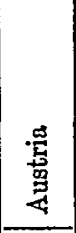 & 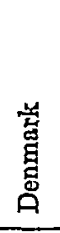 & 总 & 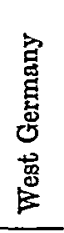 & 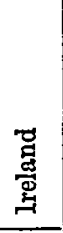 & 总 & $\begin{array}{l}\text { 宏 } \\
\text { 竞 } \\
\text { 艺 }\end{array}$ & 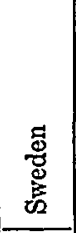 & 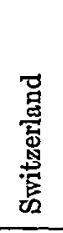 & 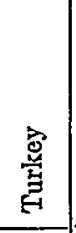 & 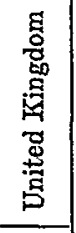 & 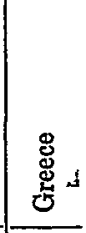 \\
\hline 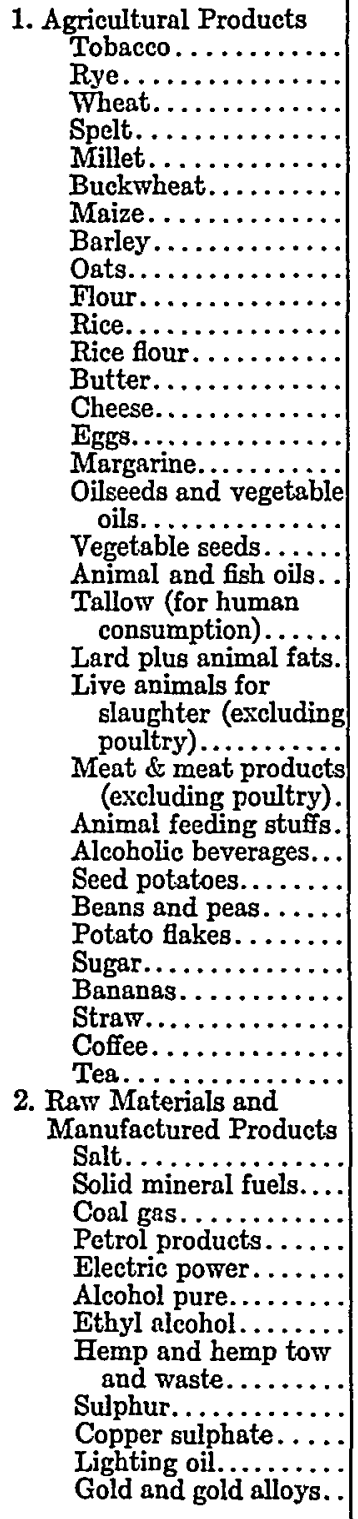 & $\begin{array}{l}\text { STp } \\
\text { STp }\end{array}$ & & $\begin{array}{l}\text { ST } \\
\text { ST } \\
\text { ST } \\
\text { ST } \\
\text { ST } \\
\text { ST } \\
\text { ST } \\
\text { ST } \\
\text { ST } \\
\text { ST } \\
\\
\text { ST } \\
\text { ST }\end{array}$ & $\begin{array}{l}\text { ST } \\
\text { ST } \\
\text { ST } \\
\text { ST } \\
\text { ST } \\
\text { ST } \\
\text { ST } \\
\text { ST } \\
\text { ST } \\
\text { ST } \\
\text { ST } \\
\text { ST } \\
\text { ST } \\
\text { ST } \\
\text { ST } \\
\text { ST } \\
\\
\text { ST } \\
\text { ST } \\
\text { ST }\end{array}$ & ST & $\begin{array}{l}\text { ST } \\
\text { ST }\end{array}$ & $\begin{array}{l}\text { ST } \\
\text { ST } \\
\\
\text { ST } \\
\text { ST } \\
\text { ST } \\
\text { ST } \\
\text { ST }\end{array}$ & $\begin{array}{l}\text { ST } \\
\text { ST } \\
\text { ST }\end{array}$ & $\begin{array}{l}\text { ST } \\
\text { ST } \\
\\
\text { ST } \\
\text { ST } \\
\text { ST } \\
\text { ST } \\
\text { ST } \\
\text { ST } \\
\text { ST } \\
\text { ST } \\
\text { ST } \\
\text { ST } \\
\end{array}$ & ST & & $\begin{array}{l}\text { ST } \\
\text { ST } \\
\text { ST }\end{array}$ \\
\hline
\end{tabular}


TABLE III-Continued

\begin{tabular}{|c|c|c|c|c|c|c|c|c|c|c|c|c|}
\hline . & 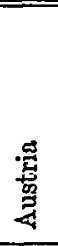 & 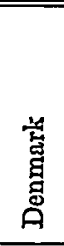 & $\begin{array}{l}\text { 芯 } \\
\text { 萤 }\end{array}$ & 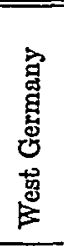 & 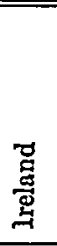 & 焉 & 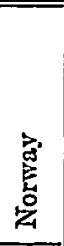 & 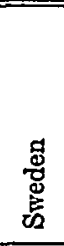 & 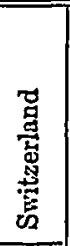 & $\begin{array}{l}\text { 兽 } \\
\text { 急 }\end{array}$ & 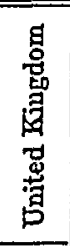 & 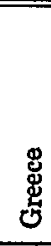 \\
\hline 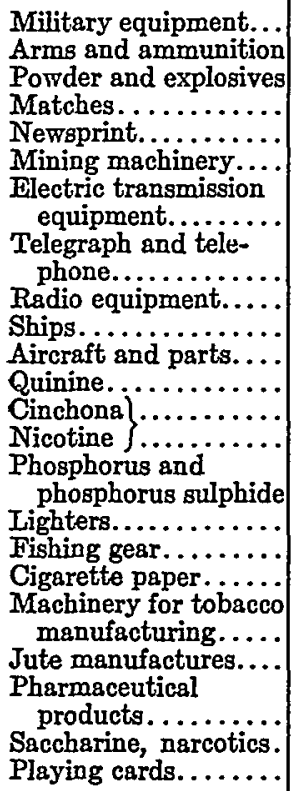 & & $\begin{array}{l}\text { ST } \\
\text { ST }\end{array}$ & $\begin{array}{l}\text { ST } \\
\text { ST } \\
\text { ST } \\
\text { ST } \\
\text { ST } \\
\text { ST } \\
\text { ST } \\
\text { ST } \\
\text { ST } \\
\text { ST }\end{array}$ & ST & & $\begin{array}{l}\text { ST } \\
\text { ST } \\
\text { ST } \\
\text { ST } \\
\text { ST }\end{array}$ & . & $\begin{array}{l}\text { ST } \\
\text { ST }\end{array}$ & STp & . & $\begin{array}{l}\text { ST } \\
\text { ST } \\
\text { ST } \\
\text { ST }\end{array}$ & $\begin{array}{l}\text { ST } \\
\text { ST }\end{array}$ \\
\hline
\end{tabular}

Note: ST=state-traded. STp=partially state-traded.

the food and feedingstuffs sector, and part two the raw materials and manufactured products sectors.

As stated above, imports on government account, on the basis of the reference year I948, account for 4.2 per cent of total intra-European imports. About three-fifths of this amount are food and feedingstuffs, the remainder being raw materials and a few manufactured products. More than three-quarters by value of the raw materials and manufactured goods imported on government account by European countries as a whole are accounted for by coal (Norway and France) and petroleum products (France). This means that 60 per cent of government imports in Europe as a whole represent agricultural products, about 30 per cent coal and petroleum, and the remainder the other raw materials or manufactured goods referred to in part two of table three.

The situation, by countries, is as follows:

\section{Austria}

The following are at present imported on government account: raw tobacco, cigars, cigarettes, salt, and alcohol. In I948, I952, 1953, and I955, imports of these 
products represented 1.04, I.30, 1.20, and 0.8 per cent, respectively, of Austria's total intra-European imports.

\section{Denmark}

State trading concerns only firearms, munitions of war, aircraft for the Danish air force, and warships. Imports of these in I948, I952, I953, and I955 represented $0.42,0.29,0.60$, and 0.43 per cent, respectively, of Denmark's total intra-European imports.

\section{France}

France is, by far, the biggest exponent of state trading in Europe. Its imports on government account amount to $5^{\circ}$ per cent of those in OEEC member countries as a whole. In the agricultural sector, government imports consist of: cereals and flour, butter, cheese, oilseeds and vegetable oils, raw and manufactured tobacco, and sugar; in the raw materials sector: solid fuels, petroleum products, gas, electricity, pure alcohol, and gold and gold alloys; in the manufactured goods sector: powders, explosives, matches, printing paper, telegraph and telephone equipment, radio, electricity transmission equipment, ships, aircraft and components, arms, and munitions. In I948, I952, and I953, combined imports of solid fuels and petroleum products accounted for 67,76 , and 79 per cent, respectively, of France's imports on government account. In the same three years, France's total imports on government account represented 22, 34, and 35 per cent, respectively, of its total intra-European imports.

\section{West Germany}

Apart from pure alcohol and matches, state trading in West Germany is confined to agricultural products. The principal imports under the system are meat and fatstock, butter, bacon, margarine, lard and other animal fats, sugar, cereals (wheat, rye, barley, oats, and rice) and coarse grains, vegetables and fats, and animal feedingstuffs. In 1948,1952 , 1953, and 1955, these imports together represented 6.9, 10.3, 8.6, and $7 \cdot 4$ per cent, respectively, of West Germany's total intra-European imports.

\section{Greece}

Greece imports the following products under state trading: matches, kerosene, playing cards, cigarette papers, saccharine, narcotics, sulphur, copper sulphate, and wheat and wheat flour. However, its imports of these from European countries represent an extremely small proportion of Greece's total imports.

\section{Ireland}

The following are imported on government account: wheat and wheat flour, sugar, maize, oatmeal, and barley. In 1948, these imports together represented 1. 6 per cent of Ireland's total intra-European imports.

\section{Italy}

State trading in Italy covers the following products: bread grains, raw and manufactured tobacco, bananas, salt, phosphorus, phosphorus sulphide, quinine and 
cinchona, nicotine, matches, flints, cigarette lighters, and other mechanical lighters. Imports of these products in $1948,1952,1953$, and 1955 represented $4.6,0.8,2$, and I.7 per cent, respectively, of Italy's total intra-European imports.

\section{Norway}

The following products are imported on government account: rye, oats, flour, wines and spirits, sugar, coffee, oilcake, coal and coke, fishing equipment, and pharmaceutical products. Coal imports alone accounted in 1948 and 1953 for $3^{8}$ and 33.2 per cent of total state trading, which itself represented 7.7 and 6.2 per cent, respectively, of Norway's total intra-European imports for those years.

\section{Sweden}

State trading accounted for 4.2, 2, 2.9, and I.9 per cent of Sweden's total intraEuropean imports in 1948, 1952, I953, and 1955, respectively. However, it will be noted that a very high proportion of the agricultural products considered to have been imported on government account, and amounting to $1.8,0.6$, 10, and 6 per cent of trade in those years, respectively, have actually been imported since $195^{6}$ under a new procedure which is, in effect, practically equivalent to liberalization. The products in question are fatstock, meat, eggs, rye, wheat, flour, and sugar. The products actually imported on government account are: alcoholic beverages (other than beer), tobacco, cigarette papers, machines for manufacturing cigars and cigarettes, arms, and military equipment.

\section{Io. Switzerland}

With the exception of pure alcohol and ammunition, Switzerland's government imports consist of a wide range of agricultural products, which alone account for 97 per cent of all state trading in 1948. The products concerned are wheat, rye, oats, barley, maize, rice, flour, margarine, edible oils, oilseed, butter, dried vegetables, seed potatoes, and animal feedingstuffs. In 1948, 1952, 1953, and 1955, Switzerland's imports on government account amounted to $5.3,3.1,4.8$, and 3 per cent, respectively, of its total intra-European imports.

\section{Turkey}

On the basis of the reference year 1948 , products now imported on government account represent 4 per cent of total imports. The system covers the following: tea, tobacco, salt, alcohol and spirits (except beer, wines, and whiskey), raw and medicinal opium, morphine and morphine salts, cocaine and cocaine salts, quinine and its derivatives, radio transmitting equipment, powders, explosives, and arms (except sporting equipment).

\section{United Kingdom}

State trading now covers only certain types of jute manufactures imported in negligible quantity in 1948 and 1952, and representing in 1953 and 1955 less than o.I per cent of the United Kingdom's total intra-European imports. 


\section{III}

\section{Methods of Administering State Trading}

\section{West Germany}

a. Cereals, fodder crops, sugar, milk, livestock. Each importer of these products is required to offer them, no later than at the time of customs clearance or on crossing the frontier, to the Import Offices, which are responsible for organizing sales on the home market. These Import Offices have the sole right of taking over such goods from abroad and retailing them; they have the option of accepting or refusing imported goods offered to them. If they do not exercise their right of purchase, the goods may not be sold, processed, or consumed in the Federal Republic. The object of the market-control legislation is to ensure adequate supplies to the population in the Federal Republic and to permit the constitution of adequate stocks. The rights of control and prohibition vested in the Federal Minister of Food, Agriculture, and Forestry guarantees, inter alia, that imports of goods subject to agricultural marketing regulations are made in accordance with the general principles laid down in section $\mathrm{D}$ of chapter four of the text of the Havana Charter.

b. Alcohol. Under the terms of various laws, the federal government has the sole right to exercise a monopoly over the import of alcohol. The Federal Alcohol Monopoly Department comprises the Federal Monopoly Office, an authority, and an operational office. The Federal Minister of Finance, whose responsibility it is to operate the alcohol control, must satisfy himself in particular that imports are made in accordance with the general principles laid down in section $D$ of chapter four of the text of the Havana Charter.

c. Inflammable materials. The federal commissioners responsible for the state control over the West German company which holds the monopoly of inflammable materials are also required to observe the same principles: the company has the sole right to import such materials.

\section{Austria}

A government monopoly over imports of the following products is maintained solely for purposes of taxation:

a. Tobacco. Imported tobacco, raw and manufactured, and tobacco products are the sole responsibility of the monopoly holder. Foreign purchases are decided on commercial grounds, with no discrimination between sources of supply.

b. Salt. The monopoly covers both home production and imports; however, as the former suffices to meet national requirements, the import monopoly is purely a matter of form. Foreign purchases of medicated salts (pure sodium chloride for injections and marine salts for therapeutic baths) are made through private firms and are subject to no restrictions.

c. Raw alcohol and spirits. These are imported through the monopoly authority. However, the authority issues import licenses to private individuals, and licences for 
the import of well-known brands of spirits commonly asked for by foreign customers are granted liberally.

\section{France}

Under the provisions of a series of laws on the nationalization of certain major French industries, special bodies were set up to administer the following sectors:

a. Solid fuels. The Association Technique d'Importation Charbonnière [Technical Association for Coal Imports] has sole authority to conclude contracts for buying and transporting imported coal and pitch.

b. Electricity-Gas. The public corporations Electricité de France (Service National) and Gaz de France (Service National) are responsible for exports and imports in their respective sectors, under contracts approved by the competent government departments.

c. Oleaginous products. The Groupement National d'Achat des Produits Oléagineux (GNAPO) [National Buying Group for Oleaginous Products] is an intertrade corporation under the authority of the Minister of Industry, operating through a government agent and subject to government audit. The Group transacts or supervises, on behalf of the Government, operations for regulating the market for certain oleaginous products: guaranteed prices for growers in Metropolitan France and overseas territories, price equalization, and imports.

d. Cereals. The Office National Interprofessionnel des Céréales (ONIC) [Intertrade Cereals Office] is a public body responsible for controlling the whole domestic market for cereals and cereal products. It performs many duties, ranging from administrative action on behalf of the Ministry of Agriculture to actual purchases and sales of cereals if the market situation so requires. It has a monopoly of imports and exports for all the products under its control.

e. Butter and dairy products. The Groupement National des Produits Laitiers (GNPL) [National Dairy Products Association] is an intertrade body under the auspices of the Minister of Agriculture, acting through a government agent and subject to government audit. The Group transacts or controls, on behalf of the Government, operations designed to regulate the market for butter and cheese: storage, guaranteed prices to the producer, price equalization, and imports.

f. Crude petroleum products and derivatives. The Ministry of Industry and Commerce (Motor Fuels Directorate) fixes distribution quotas for each importing company; the quota determines how much crude shall be refined by each. Similarly, imports of petroleum derivatives must be made within the quotas fixed by the Ministry of Industry and Commerce, in accordance with the import program prepared by the Ministry.

g. Newsprint. The Société Professionnelle des Papiers de Presse [Newsprint Trade Association] is responsible for the import of newsprint. It operates under government control exercised by government agents.

h. Tobacco and matches. The Service d'Exploitation Industrielle des Tabacs et 
Allumettes (SEITA) [Industrial Service for Tobacco and Matches] has a monopoly over tobacco growing, tobacco imports, tobacco manufacture and sales, and over the purchasing, manufacture, and sale of matches. This is. a fiscal monopoly, the revenue from which is kept separate from the central budget and allotted to the amortization of the public debt through an autonomous fund. SEITA controls commercial operations, and the Directorate-General of Indirect Taxation is responsible for the fiscal side.

i. Powders and explosives. These are administered by the Powders Service, which is attached to the Ministry of National Defense. There is practically no international trade in such products.

j. Alcohols. The state has a monopoly over the production of ethyl alcohols (except brandies and alcohols entitled to a controlled appellation of origin, and proof spirits) exercised through the Alcohols Department. The Government also has a monopoly over the import of alcohols produced in, or consigned from, foreign countries, overseas territories or associated territories, and states of the French Union.

k. Sugar. In recent years the conversion to alcohol of any surplus sugar beet produced has led to overproduction of alcohol, representing a heavy charge on the French budget. In order to limit alcohol production, the Groupement Interprofessional Betteravier [Beet Inter-trade Association] has been set up to control beet and sugar production by limiting the guaranteed price to a single figure for a specified quantity of beet. This body is a public corporation responsible to the Ministry of Agriculture, and takes part in all studies on foreign trade problems.

\section{Italy}

a. Bananas. The banana monopoly is mainly designed to provide markets for the fruit produced in Somaliland, and was entrusted to Italy by the United Nations. The monopoly authority also obtains supplies from other countries.

b. Wheat and flour. Purchases are made on behalf of the Government by the Federation of Agricultural Consortia. The policy regarding wheat imports takes into account Italy's commitments under the International Wheat Agreement and must comply with internal regulations designed to support this essential branch of agriculture. In addition, it is intended to insure sufficient supplies to meet national requirements.

c. Tobacco, tobacco extracts, and juice; sea salt, rock salt, and mineral salt; phosphorus and phosphorus sulphide; nicotine and nicotine salts; mechanical lighters, matches, and fints. Imports of these are, for fiscal reasons, subject to state trading. They are made on government account and sold by government-appointed retailers at controlled prices.

d. Quinine. Imports of quinine are also a government monopoly, with a view to insuring adequate supplies for the home market at a reasonable price. Private 
bodies may, however, be authorized to import this commodity on payment of a fee beforehand.

e. Gold and gold alloys. These can only be imported through the Italian Exchange Control Office acting on behalf of the Italian Minister of Finance.

\section{Denmark}

a. Firearms, munitions, aircraft, aeroplanes, and vessels for military use. Government imports come under the national defense budget.

\section{Ireland}

a. Wheat, barley, maize, flour. The sole importer of these cereals in Ireland is Grain Importers (Eire) Ltd., a government undertaking responsible for reselling to distributors and millers at prices fixed so as to maintain a balance between prices of home production and imports, and also taking account of the controlled selling price of flour. In this way, it maintains stable and uniform prices in the interests of livestock farmers and permits millers to trade with their authorized profit margin. Any losses incurred by this body are covered by the state.

\section{Greece}

Certain products are made subject to state trading for reasons of public health or public interest, or for taxation purposes. As a rule, state trading does not aim at restricting imports unduly, nor at protecting home industry or agriculture. The products affected may be divided into three categories:

a. Matches, kerosene, cigarette rice paper for tobacco producers, saccharine, and narcotics. These are monopoly products imported under the control of the Ministry of Finance.

b. Wheat and flour. These are imported on government account-i.e., by the Ministry of Commerce-under the International Wheat Agreement. The private sector may, however, subject to special authorization, import wheat and wheat flour.

c. Sulphur, copper sulphate, and fertilizers. These are imported by the Agricultural Bank of Greece on government authorization. The main purpose of the Bank is to keep prices at a minimum by means of large-scale imports and to standardize prices all over the country, so that the mountain districts furthest away from the ports are not penalized as compared with other more accessible districts.

\section{Norway}

a. Cereals. The state has a monopoly over the import of wheat, rye, barley, and oats and over all milled products of these cereals. A permanent body has been set up-the National Cereals Office-with the sole right of purchase and sale of the products in question; exports require the authorization of the competent ministry. The National Cereals Office is obliged, while paying price-support premiums, to purchase home-grown cereals and to import cereals and cereal products in sufficient quantities to cover national requirements. The purchasing price of national products 
is fixed on the basis of the import price, plus the premium, which may vary according to the scale of requirements. In the case of animal feedingstuffs, the competent body controls consumption in the light of social considerations and may impose internal taxes in order to adapt the size of the livestock herd to the country's requirements. The revenue from such taxes is used to develop production and trade in the products in question.

b. Alcoholic beverages. The Wine Monopoly, Ltd., has the sole right to import, produce, and export alcoholic beverages. It is also responsible for sales on national territory. Prices must be no higher than is necessary to ensure a reasonable profit. The net profits are used for social purposes and in the public interest; at least 20 per cent of the net annual revenue must be credited to the Anti-Alcoholic Fund.

c. Fishing equipment. The National Fishing Equipment Office has the sole right to import a series of articles in so far as they are used as fishing tackle or for the manufacture of such tackle: hemp, cotton, nylon (raw or more or less heavily processed), lines, and hooks. The Office may, when it thinks fit and with the approval of the competent ministry, authorize imports of these products on private account. The list of products affected can be extended, provided the products in question have a similar end use. The sale in Norway of products which have not been imported through or with the approval of the National Fishing Equipment Office is prohibited. The Office may be instructed to import and store exceptional quantities of fishing tackle or products for its manufacture in order to ensure the country's supplies of such equipment; it may also apply the restrictive measures necessary for the efficient organization of the production and sale of fishing tackle.

d. Pharmaceutical products. The Norwegian Center for the Import of Medical Supplies has the sole right to import specific pharmaceutical products; it also has the sole right to sell on the home market to pharmacists, industrial producers, and craftsmen using these goods in the exercise of their trade, and to public laboratories and scientific centers. However, the sale to pharmacists of medicines and raw materials for the preparation of medicines is not covered by these provisions. In addition, the Ministry of Social Affairs may authorize derogations from these provisions, in particular for the import and sale of insecticides.

e. Solid fuels. The Fuel Import Office has the sole right to import hard coal and coke. Nevertheless, industrial undertakings, the Norwegian railways, and private shipping companies can continue to import these products directly, unless the Ministry of Commerce decides to the contrary. The Ministry may also authorize direct imports by other firms and may, moreover, instruct the Fuel Import Office to import certain quantities of hard coal and coke.

f. Coffee, sugar, and syrup. Following an agreement concluded on April 28, I954, by the Ministry of Commerce and the Wholesalers' Federation, the board set up after the war by the Norwegian Grocers' Federation for the import of the above commodities maintains its powers, unless the agreement is denounced with six months' notice. New import quotas can be established only with the consent of 
the board. Stocks of sugar and coffee must be kept at a level sufficient to cover the country's requirements for two or three months.

\section{Sweden}

a. Wines and alcohols. Trade in alcoholic beverages (liqueurs, wines, and strong beers) is under state control, primarily for reasons of health and for political and financial considerations. The legislation is based on the principle that trade in these products should not be a source of profit to private individuals and must be carried on in such a way as to reduce as far as possible the disadvantages connected with the consumption of alcoholic beverages. The law provides for a wholesale company and a retail company. Both companies are organized as commercial undertakings and conclude agreements of limited duration with the Government. By virtue of these agreements and the provisions of their articles of association relating to management, profits, tax collection, etc., the state controls the management of these companies. Raw potato alcohol is manufactured in Sweden in some eighty private distilleries, and cellulose sugar alcohol in several pulping plants using the sulphite process. This production, too, is supervised by the monopoly.

b. Tobacco and machines for the tobacco industry. The tobacco import monopoly is not absolute, and retailers approved by the monopoly are authorized to import these products. Machines for the tobacco industry, cigarette paper, and cigarette holders can be imported only by the tobacco monopoly or with the approval of the public authorities. The tobacco monopoly is under state control. The retail trade in tobacco products is in the hands of private enterprise. Prices are fixed by the tobacco monopoly and include the taxes established by Parliament.

c. Agricultural products. The government agencies responsible for the import and sale of fatstock, meat, eggs, rye, wheat, and sugar have been maintained, but in conditions almost equivalent to liberalization.

d. Defense equipment. These goods are generally imported by government purchasing agencies. Some consignments may, however, be imported by private companies acting on behalf of the Government.

\section{Io. Switzerland}

a. Wheat. The Federal Wheat Administration is a division of the Federal Department of Finance and Customs. The centralization of imports in the hands of the Administration is, for the time being, essential, owing to the control of bread prices, which are kept down by government subsidies, and also in order to protect the Swiss milling industry, which the Confederation is obliged to support. Both measures (centralized imports, and protection of the home milling industry) are legally based on the addition to the Federal Constitution accepted by popular vote on November 23, 1952 .

b. Fodder grains and feedingstuffs. Under the Federal Order of December I7, I952, which forms the new legal basis of the CCF, the latter is constituted as a cooperative company under public law and is placed under the supervision of the 
Federal Council. Its statutes and, consequently, any amendments thereto must be submitted to the Federal Council for approval. The members of this organization are firms engaged in international trade in the goods in question. The CCF is, therefore, a trade syndicate with a legal import monopoly.

Even on its creation in I933, the CCF's functions related to commercial as well as agricultural policy. Its functions in the field of commercial policy consisted, from the very beginning, in promoting the whole Swiss exporting economy as far as possible by exerting an influence on the sources of the categories of imports within its competence. Thus, on the entry into force of the European Payments Union, every effort was made to increase imports of the goods in question from members of the Union. The CCF's functions with regard to agricultural policy consist in influencing, to a limited extent, the import prices of goods under its control in order to prevent market saturation and thus avoid overproduction of milk, dairy products, meat, and animals fats.

c. Butter. The monopoly of butter imports is held by the Swiss Butter Supply Center (BUTYRA), which is a government-controlled cooperative of firms and organizations permanently engaged in the wholesale butter trade. Founded in 1932, BUTYRA was approved as a public cooperative society, within the meaning of article 829 of the Code of Company Law, under the new agricultural legislation which came into force on January $I$, I954. The structure and functions of BUTYRA are also defined in this legislation. The implementation of its duties is controlled by the competent government services.

BUTYRA's main function is to regulate butter imports in such a way that demand for the various qualities can be met without hampering the marketing of Swiss butter. It also distributes imported and home-produced butter. Finally, it is required to purchase any surplus Swiss butter and find a market for it. BUTYRA has the sole right of importing butter, by virtue of a general import license from the federal administration concerned. Butter is bought from the foreign suppliers by BUTYRA, and not by its individual members, and imported into Switzerland for retailing through the trade. As stated above, the volume of butter imports is regulated to suit domestic requirements.

d. Alcohols. The federal alcohol monopoly, which is a division of the Federal Department of Customs and Finance, is the competent authority. The monopoly is based on article thirty-two of the Federal Constitution, under the terms of which the Confederation is required to ensure that legislation is directed towards curbing the consumption, and, therefore, the importation and production, of spirits. Over 75 per cent proof alcohol, together with "trois-six" and spirits of wine (denatured) may be imported only through the federal alcohol monopoly. On the other hand, less than 75 per cent proof alcohol is not subject. to the monopoly and may be imported with no further. formality by private individuals, on payment of the customs duties prescribed in the tariff and the monopoly dues. As a rule, 8o per cent 
of the country's requirements of refined "trois-six" can be met from home production, and imports merely make up the difference.

e. Munitions. The Military Technical Service (STM) of the Federal Military Department is responsible for the implementation of the powder monopoly. The latter is based on the Federal Constitution, article forty-one of which gives the Confederation sole rights in the manufacture and sale of gunpowder, and places under its authority the manufacture, purchase, trade in, and distribution of, firearms, ammunition, explosives, other war material, and components. The Federal Constitution provides that imports of arms and munitions shall also be subject to authorization by the Confederation (STM). All ammunition, whether for the forces or for sporting guns, is exclusively of Swiss manufacture. Imports are limited to ammunition for adjusting and testing arms for delivery abroad.

IV

\section{Reasons for Retaining State Trading and the Resulting Disadvantages for the Countries' Trading Partners}

The preceding sections show, first, that, after assuming great prominence in OEEC countries' import trade after World War II, state trading has declined considerably over the last few years. It may be inferred that there were exceptional reasons for its previous predominance. Clearly, these are connected with the strict wartime controls which governments were obliged to impose on their economies during hostilities and in the immediate postwar years.

During the war, governments were compelled to introduce strict economic planning, with a view to making the most efficient use of available resources, having regard to the ends pursued. It was a time of compulsory allocation of raw materials, rationing of consumption, exchange controls, etc. Obviously, discipline imposed from above on economic activities was bound to take the form of domestic and foreign trade controls. Such controls could best be operated if the government directly assumed responsibility for some kinds of economic activity. Incidentally, in many cases, it delegated its powers to nongovernmental bodies (import associations) which could only import, export, allocate, and distribute goods in accordance with instructions from the central government.

When supplies again became plentiful, the tendency to return certain sectors to private enterprise within a liberal system eventually won the day. Hence, the gradual decline in state trading, going hand-in-hand with the abolition of exchange controls, the quota system and price controls, and internal and external trade controls. It is, nonetheless, true that vestiges of the wartime system still persist in some countries. While some sectors are now almost wholly in private hands, imports of the basic products they use are still subject to government monopoly or delegated to some nongovernmental association.

Secondly, the present situation shows that most of the remaining state trading concerns agricultural products and foodstuffs. This is accounted for by the fact 
that agriculture is given special treatment in most West European countries. In order to support farmers' incomes, the government in these countries regulates production in one form or another, fixes prices of produce, and exercises strict control over imports and exports. Action by the government also includes the fairly general grant of financial subsidies to agriculture in some form or another. In many countries, the methods used for government action in this field (e.g., government agencies for purchasing, stocking, and marketing, etc.) have led to imports on government account or, failing this, to the delegation of monopoly rights in respect of imports to nongovernmental bodies subject to strict government control.

The main reasons for retaining state trading in the case of other products are:

a. fiscal: in some countries, production and sales of certain products (e.g., tobacco, matches, and alcohol) are a substantial source of revenue; strict government control is, therefore, imposed, either by manufacturing such products in government factories or by government-controlled distribution; and in such cases, foreign trade in these products is also handled by the government;

b. health: in the case of alcohol, pharmaceutical products, and narcotics, the state controls trade and consumption in order to safeguard public health; and

c. military: arms, munitions, aircraft, and radio equipment.

In a given country, there may be social reasons applicable to certain categories of the population (e.g., fishing equipment in Norway) or special historical reasons (e.g., salt in Austria, bananas in Italy) to account for state trading.

It will be noted that where state trading exists, this does not necessarily imply that the undertakings through which the system is administered are state-owned. There may be a state import monopoly, without ownership of any of the firms manufacturing, distributing, or consuming the imported product on the domestic market. Conversely, in some countries, where the major part of some particular economic activity is state-controlled (nationalized sectors), the state does not necessarily have a monopoly of imports. State-owned or state-administered firms (having, as a rule, a considerable financial or managerial autonomy) are conducted just like private undertakings in respect of imports.

The retention of state trading in some countries for particular products is, nevertheless, objectionable to their trading partners who export such goods. The OEEC system for the liberalization of trade was based on importers' freedom to select suppliers as they choose and on the principle of nondiscrimination among suppliers. The arrangements for progressive stages of liberalization based on percentages were worked out in a spirit of reciprocity, and each country might, when freeing some portion of its imports, justifiably hope that its exports would be given comparable treatment by its partners in virtue of their own measures for the liberalization of imports.

In fact, it became clear from the very outset of the OEEC liberalization scheme that the freeing of imports on government account was devoid of meaning. As the state has a monopoly of imports, it can select its suppliers not merely for commercial 
considerations (e.g., price, quality, and delivery dates), but on other grounds. Hence, the OEEC liberalization percentages were calculated on the basis of private imports only, and it proved impossible to attempt, in respect of government imports, a comparable standardization to that which was successfully attempted in the private sector.

The consequences of the liberalization of private imports is to enable the consumer in a particular country to choose his own suppliers at home and abroad in the light of his own advantage. This leads to open competition among suppliers, with the best man winning. On the other hand, when imports of a product are a government monopoly, the consumer can only buy what the government, as sole arbiter of quantity, quality, origin, and timing, chooses to import. State trading is, therefore, usually criticized as encouraging protectionist, restrictionist, and discriminatory trends, and as contravening the spirit of the liberalization of imports as laid down in the principles of the OEEC, GATT, and IMF.

Another criticism is that it makes trade unstable. The import policy followed by government agencies, notably in the case of agriculture, is directly conditioned by production and price trends on the home market and is affected by fluctuations in them. Hence, exporting countries can never rely on a firm demand in importing countries, and this has repercussions on their own production. Of course, these drawbacks may, to some extent, be lessened by negotiating bilateral agreements between government importing agencies and foreign exporters. Generally speaking, however, the exporting countries regard such agreements as inadequate and accuse bilateralism of being a source of discrimination.

In contrast, it is noted that state trading is a means of regulating home and foreign markets, as the state has the financial means of building up stocks during times of surplus and gradually releasing them when there is a shortage. It is also noted that state trading has, so far as Europe is concerned, made it possible to buy from certain economically underdeveloped countries products which they would never have been able to sell had there been no state trading by their partners, as private importers would have gone to other sources.

\section{$\mathrm{V}$}

\section{Rules Governing State Trading in the OEEC and the EUROPEAN ECONOMIC COMMUNITY}

Neither the rules of the OEEC nor subsequently those of the Treaty of Rome have ever purported to forbid member countries to exercise the right of adopting state trading for any particular product. Countries retain their sovereign rights in the matter, and if, for reasons of which they are sole judge (e.g., political reasons) they decide to place imports of a product under government control, they are quite at liberty to do so. However, a certain amount of moral pressure has in recent years been exerted within the OEEC in order to: 
a. limit recourse to state trading; and

b. induce countries retaining state trading to endeavor to administer it as liberally and with as little discrimination as possible.

As stated above, in the OEEC, state trading was left out of the calculation of liberalization percentages: This means that when the OEEC decided that 75 per cent or 90 per cent of imports should be freed, the figure was calculated on the basis of private imports only. The sole measures taken with regard to state trading consisted in the declaration in article twelve of the code of liberalization that,

Member countries, to the fullest extent of their executive authority, shall ensure that import trade handled by monopolies under government control is conducted, in respect of other Member countries, in accordance with the general principles laid down in Section D of Chapter IV of the text of the Havana Charter.

Later, the OEEC introduced a system for the examination of state trading in order to ascertain the list of imports on government account and verify whether countries were complying with the principles of the Havana Charter. Article thirty of the code of liberalization states:

a. Member countries shall notify to the Organisation within the periods determined by the latter:

(i) the commodities imported by monopolies under Government control;

(ii) in the case of each commodity, the method of operation of the import agencies; and,

(iii) where appropriate, the reasons for which any such commodities are not imported in accordance with the general principles laid down in Section D of Chapter IV of the text of the Havana Charter.

b. Member countries shall submit the same notification to the Organisation without delay when the import of any commodity, hitherto imported on private account, is transferred to a monopoly under government control, and shall give an explanation of the reasons for such a transfer.

c. Member countries shall also notify to the Organisation without delay the transfer to private account of any commodity hitherto imported by a monopoly under government control.

d. The Organisation shall consider the notifications submitted to it in accordance with the provisions of paragraphs (a) and (b), with a view to determining whether each Member country is complying with its obligations under Article r2. The organisation shall also consider the reasons for the transfers referred to in paragraph (b).

It must be admitted that this examination procedure has not yielded any great results. At the instigation of countries exporting agricultural products which are subject to state trading in large importing countries, the Organization strengthened these rules in 1955 .

It also evolved a procedure for complaints by member countries against a country practicing state trading:

The Organisation shall examine cases in which a Member country considers that the 
import trade notified as State trading of another Member country is conducted in a manner which has the same effect as if that trade were subject to quantitative restrictions.

In addition, provision was made for a systematic review of the transfers of a given product from private trading to state trading:

When, in accordance with Article 30 of the Code, a Member country notifies to the Organisation the transfer to a monopoly under Government control of the import of any commodity previously imported on private account, the Organisation shall examine whether that import trade is conducted in a manner which has the same effect as if it were subject to quantitative restrictions.

If, upon the examination of the two cases just referred to, the administration of the import trade in question is found to be restrictive in character, the Organization may decide that the trade in the commodities concerned should no longer be excluded from the computation of the percentages of liberalization, and, as such, should be deemed to be subject to quantitative restrictions.

This sanction calls for a few comments. To begin with, it will be observed that the country in question is neither requested to transfer the imports to private account nor to administer imports on government account more liberally. In short, membercountries retain full freedom in the matter. The sanction is that such imports shall be included in the computation of the liberalization percentages in the same way as nonfreed imports. Its effect is, therefore, to lower the percentage of liberalization officially reached by the country concerned. Should the country thereby fall below the compulsory percentages fixed by the OEEC, it is obliged, in order to get back to the right level, to abolish quantitative restrictions on certain goods imported on private account or, failing this, to invoke the escape clauses of the code of liberalization, when it will become liable to examination by the OEEC.

Actually it is extremely difficult to enforce these provisions. To begin with, exporting countries are reluctant to complain to the Organization against the importing countries. Secondly, when they do so, the result is bound to be disappointing, for the following reason: If the Organization is to decide that the product concerned must be regarded as subject to quantitative restrictions for the purpose of the compilation of liberalization percentages, it is necessary, under its fundamental rules of procedure, that the decision shall be unanimous-i.e., with the agreement of the country against which complaint has been lodged.

The Organization has also endeavored to devise rules regarding the administration of state trading, with a view to at least reducing its discriminatory factorsfor example, by requiring monopolies to invite public tenders. This has, however, been fruitless. Furthermore, it must be admitted that in the agricultural sector, where there is most state trading, any improvement in administrative procedure is directly bound up with the whole agricultural policy of the countries concerned. Hence, the Organization's endeavors to coordinate agricultural policies. Clearly, however, such a vast problem goes beyond the framework of this study. 
When preparing the Treaty of Rome, the six countries of the European Economic Community also came up against the problem of state trading. They formulated rules on the subject, notably in articles thirty-seven and ninety of the Treaty. Article thirty-seven, which forms part of the chapter on the elimination of quantitative restrictions as between member-states, stipulates that,

Member States shall progressively adjust any State monopolies of a commercial character in such a manner as will ensure the exclusion, at the date of the expiry of the transitional period ( 12 to 15 years), of all discrimination between the nationals of Member States in regard to conditions of supply or marketing of goods.

This progressive adjustment shall proceed at the same rate as the elimination of the remaining quantitative restrictions on private trade between member-states. Should a country fail to maintain the rate of progress, its partners may, subject to authorization by the institutions of the Community, takes measures of protection against it. Article ninety, which forms part of the chapter concerning rules governing competition within the Community, forbids restrictive and discriminatory practices by public enterprises as well as private enterprises and monopolies.

It is still too soon to know whether the principles laid down in articles thirty-seven and ninety of the Treaty of Rome will be put into effect. The institutions of the Community will supervise their implementation and will undoubtedly, as the years go by, make suggestions concerning their practical application. They may perhaps take up the idea of requiring state monopolies to invite public tenders, though this seems hardly likely at the present time. However, in this case too, as the six memberstates include two large countries, France and West Germany, which practice state trading on a wide scale in the agricultural sector, the rules on state trading will be inseparable from those governing the internal and external agricultural policy of the Community. In this respect, it should be noted that article thirty-seven of the Treaty, quoted above, explicitly provides that:

In the case of a monopoly of a commercial character which is accompanied by regulations. designed to facilitate the marketing or the valorisation of agricultural products, it should be ensured that in the application of the rules of this Article equivalent guarantees are provided in respect of the employment and standard of living of the producers concerned, due account being taken of the timing in respect of possible adjustments and of necessary specialisations.

It will be no easy matter to reconcile the principles of a liberal and nondiscriminatory administration of state trading within the Community with the need to maintain employment and standards of living in agriculture.

Experience in the OEEC and the EEC goes to show that there are strong tendencies to improve methods of administering state trading, and, while leaving governments free to retain this type of imports, to limit its arbitrary and discriminatory character. It is obviously only through ever closer cooperation between governments that any improvement in existing systems can be achieved. 